\title{
Returned to the People: The Transformation of Egyptian Royal Palaces into Museums
}

\author{
Hanan Ismail
}

\begin{abstract}
The palaces of Muhammad 'Alī's dynasty cost a fortune to build and maintain. After the 1952 Revolution, most of these palaces were confiscated and became the property of the Egyptian government. Some of them were turned into historical museums. Once opened, the palace museums attracted many visitors. This paper examines how three of these palaces - 'Abdīn Palace; Farouq Rest House and Manyal Palace - functioned as museums in post-revolutionary Egypt, and how heritage functioned in the process of building the modern Egyptian nation state in the $20^{\text {th }}$ century. These three palaces were opened as historical museums because of their historical, architectural and artistic values. The important symbolic functions of the palaces are reflected in the involvement of the highest politicians in the opening ceremonies. Nowadays, even though the studied palaces are not currently common on the tourist itinerary, they are still part of the cultural program of Egyptian school classes.
\end{abstract}

\section{Keywords}

‘Abdīn Palace - Farouq Rest House - Manyal Palace - historical museums - palaces of Muhammad 'Alī’ dynasty

\section{Introduction}

While Egypt is most famous for its pharaonic remains, it was also enriched by spectacular palaces built during the reign of Muhammad 'Alī' dynasty (1805-1952). These palaces cost a fortune to build and maintain. After the 1952 revolution, all the palaces of the king and most of the palaces of the royal family were confiscated and became the property of the government. Some of these palaces were turned into historical museums presenting Egyptian élite life as it had been lived inside. These museum palaces play an important role in preserving the national identity of Egypt and represent a vital part of its heritage.

\section{Royal Palaces and the Formation of Post-Revolution Egyptian Identity}

Between 1858 and 1908 imperialism and archaeology in Egypt were closely linked. Europeans were the founders of the Egyptian Antiquities Service and the four museums. ${ }^{1}$ These museums remained largely European-dominated until the 1950s, when the Egyptians realized the vital role of archaeology in shaping their national identity. Nationalists challenged both the European control of Egypt's archaeological institutions and Western imperialist's interpretations. ${ }^{2}$

In fact, museums were important arenas in the struggle for national independence. ${ }^{3}$ Museums are human society's equivalent of cultural memory banks. Only museums uniquely collect, preserve, research, and publicly display objects as an essential function of their existence. They help in the shaping of the cultural values. ${ }^{4}$ The new regime after the outbreak of July revolution in 1952 tried to recast the local history as the history of an Egyptian nation. ${ }^{5}$

\footnotetext{
${ }^{1}$ The Egyptian Museum (Cairo, 1906), Graeco-Roman Museum (Alexandria, 1892), Coptic Museum (Cairo, 1908) and Islamic Art Museum (Cairo, 1903). ${ }^{2}$ Donald Malcolm Reid, Whose Pharaohs? Archaeology, Museums, and Egyptian National Identity from Napoleon to World War I (London: University of California Press, 2002), 1-7.

${ }^{3}$ Reid, Whose Pharaohs?, 10, 118-119, 205.

${ }^{4}$ David Dean, Museum Exhibition Theory and Practice (London: Routledge, 1998), 1- 2,7.

${ }^{5}$ Timothy Mitchell, Rule of Experts Egypt, Techno-Politics, Modernity (California: University of California, 2002), 13.
} 
Actually, the revolution marked an important episode in the history of Egypt as it announced the arrival of a completely new era. The royal palaces were an essential link in the chain of Egypt's history as representatives of the most recent Egyptian kingdom. Their appropriation also functioned as powerful symbols of the new era that had started. Next to the already existing museums, the palaces represented the last phase of Egypt's history. The important symbolic function of the palaces is reflected in the involvement of the highest politicians in the opening ceremonies. The first Egyptian president, Muhammad Naguib (1952 1954) visited these royal palaces accompanied by army officers and his visit was recorded by journalists. ${ }^{6}$

\section{From Palaces to Museums}

The new regime considered the royal palaces symbols of the ancient regime that was replaced. These palaces contained valuable artistic objects. To have a better idea of the palaces under discussion, here is a short description of them, their history and the most important artifacts that they contain in addition to their historical and cultural value.

\section{Three Palaces}

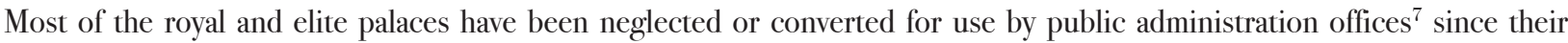
appropriation by the state, but the three palaces studied here were opened as historical museums because of their architectural and artistic value. They are of different types: one is a royal palace, 'Abdīn Palace, the second is a king's rest house, Farouq Rest House at Helwan, and the third is a crown-prince’s palace, Manyal Palace.

These palaces form an important part of the Egyptian national heritage. Since museums are considered the most comprehensive and most appropriate institution for ensuring the safekeeping of ethnological heritage ${ }^{8}$, their management is not limited to transmitting and receiving them. As a heritage, they should be preserved and, even more importantly, enriched. ${ }^{9}$

\section{- Abdin Palace}

Abdin Palace ${ }^{10}$ symbolizes the beginning of modern Cairo, as it was built to give Cairo a European style layout. ${ }^{11}$ It is considered the most beautiful of the palaces of the dynasty of Muhammad 'Alī. ${ }^{12}$ It is the only one of the 30 lavish palaces that Ismail built during his reign that he kept for himself. ${ }^{13}$ It was also his favorite place for winter receptions because its location was close to the large hotels at Azbakiyya. ${ }^{14}$ Although the palace is the smallest in size, it became the most important one from a political perspective. ${ }^{15}$ It is connected with several important historical events, such as the 'Urābī revolution ${ }^{16}$, the 1919 revolution, the

\footnotetext{
6"M' al-rảis Muḥammad Nagib fî Qașr Rảs al-Tīn", Al-Mușwir, Sep. 26, 1952 http://modernegypt.bibalex.org/DocumentViewer/TextViewer.

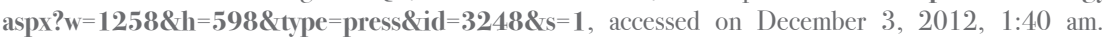

${ }^{7}$ It is also worth mentioning here that archaeologists nowadays are against using these marvelous buildings for administration offices of the presidency or any kind of activity of daily life that may affect the building. They support the idea of opening them to the public as museums because of their historical and artistic value. (Tawfĩq, 〈Kunwz 'tharīa w mi'mārīa', 3.)

${ }^{8}$ Alpha Oumar Konaré, «Museums and Ethnological Heritage`, (paper presented in Proceedings of the 12th General Conference and 13th General Assembly of the International Council of Museums, Mexico City, October 25- November 4, 1980), 65-67.

${ }^{9}$ Pedro Ramírez Vázquez, ‘The Future of Heritage and the Heritage of the Future`, (paper presented in Proceedings of the 12 th General Conference and 13 th General Assembly of the International Council of Museums, Mexico City, October 25- November 4, 1980), 48-54.

${ }^{10}$ The palace is also known under many other names: «Jawhart al-Qușwr» the jewel of palaces, «al-Jana al-Mafqwda» the lost paradise, and «Manārat al- Qușwr al-Malakya» the beacon of the royal palaces.

11 ¿Abdine Palace Museums.

12 Tawfìq, 〈Kunwz ’ tharīa w mi‘mārīa`, 3.

${ }^{13}$ Rāfíī , 'Așr Ismā‘ îl, vol. II, 55. ; Maḥmūd 'abās Āḥmmad 'Abd el-Raḥman, Al-Quuṣūr al-Malakia fĩ Miṣr Tārīkh w Haḍara (1805-1952) (Cairo: Al-Dār Al'ālamīa lil Nashr w al-Tawzi' , 2005), 83.

${ }^{14}$ Edwin De Leon, The Khedives's Egypt (London: Sampson Low, 1877), 174-175.

${ }^{15}$ Mahmoud El-Gawhary, Ex-Royal Palaces in Egypt From Mohamed Aly to Farouk (Cairo: Dar Al-Maaref, 1954$), 16$.

${ }^{16}$ For further reading about 'Urābī and 'Abdīn palace see: Mary Rowlatt, Founders of Modern Egypt (London: Asia Publishing House, 1962), 53-58, 145156.
} 
events of $4^{\text {th }}$ of February 1942 and the 1952 revolution. ${ }^{17}$ It took its name from 'Abdin Bey ${ }^{18}$, its original owner. ${ }^{19}$

Its construction in 1863 cost over half a million pounds ${ }^{20}$, in addition to the furniture which was estimated at 2 million pounds. ${ }^{21}$ The royal court moved from the citadel to 'Abdin in $1874 .{ }^{22}$ Since this date, the palace became the official dwelling of all the subsequent rulers of Egypt. ${ }^{23}$ Later, it became called the Republican 'Abdin Palace, the state headquarters of the president of the Arab Republic ofEgypt. ${ }^{24}$

All the successors of Ismail added certain elements to the palace..$^{25}$ Nāṣir used it as an official residence, while Sādāt used part of the palace only. ${ }^{26}$ On 22 January 1972, it became the presidential palace. All presidential councilors' offices, secretaries, trustees and honors records were transferred to 'Abdin Palace. ${ }^{27}$

The Italian architect De Curel Del Rosso was assigned to design the palace. ${ }^{28}$ A large number of Egyptians, Italians, French and Turkish were employed in its construction. ${ }^{29}$ The palace consists of two floors. The main entrance is located in the northern façade. ${ }^{30}$ The architectural style of the palace follows the Neo-French-Renaissance Style. ${ }^{31}$ The interior decorations combine diverse styles. ${ }^{32}$ In contrast, the corridors between the rooms are kept plain. ${ }^{33}$

Many of the rooms were reserved for members of the royal family such as the Queen's mother, or for other privileged members of the household, such as the English tailor "Mr. Laurence". Some of the spaces stand out through their decoration or function. The Suez Canal Salon, where the celebration of the inauguration of the Suez Canal took place, is an example. On the same floor, there is the billiards room, which was presented by Empress Eugénie to khedive Ismail, as well as the small dining room and the king's study. ${ }^{34}$ The palace contains also a theater, which is considered to be more splendid than the Khedival Opera House. ${ }^{35}$

The palace library, ${ }^{36}$ constructed by Khedive Ismail, contains a valuable book collection. It was accessible only to a privileged minority. There is also another separate building in the 'Abdin palace for keeping the historical documents (archives) of particular interest to the royal family. ${ }^{37}$ It also had a dental and a medical clinic, a delivery room and a pharmacy. ${ }^{38}$ It is also one of the richest in the world regarding the number of clocks scattered in the lobbies and suites. Some remarkable objects include the green telephone apparatus in the King's quarters which connected the king with the members of his cabinet through a special internal network. ${ }^{39}$ The palace also housed governmental and private ironing firms, an engineering workshop and a

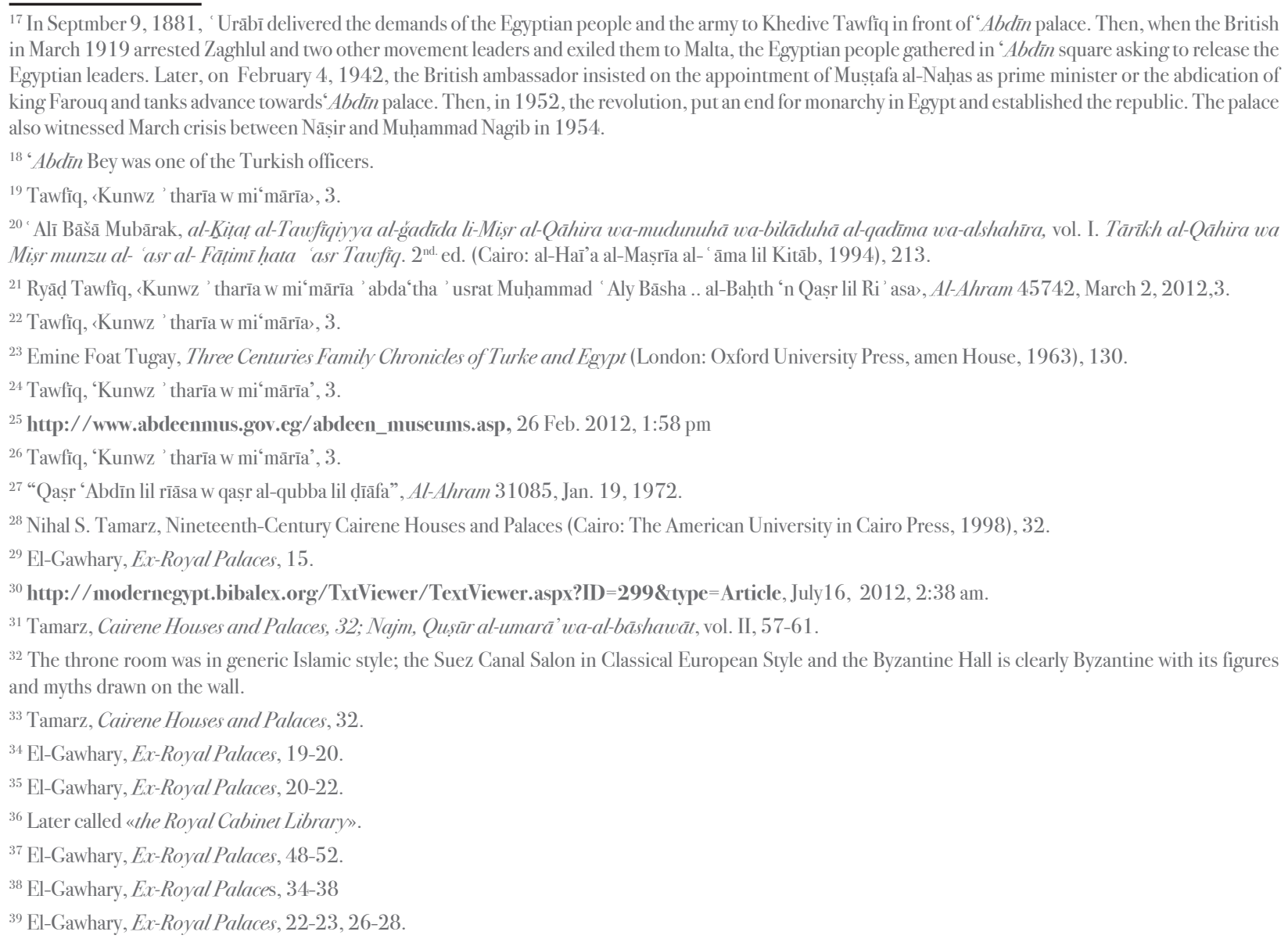


studio for photography. ${ }^{40}$

King $\mathrm{Fw}^{\prime}$ a $\mathrm{d}$ dedicated some of the halls of the palace to be used as museums of family weapons and medals. ${ }^{41}$ King Farouq completed the museum and added different kinds of weapons ${ }^{42}$, and an annexed library specialized in this field. ${ }^{43}$ In 1936 , the contents of the military museum were registered in printed books. Another museum, a silver work museum, which exhibits all the necessaries for festivals, is the most interesting on the ground floor. A workshop is annexed to the museum for mending these silver objects and testing gold by an old goldsmith, who did that work without payment. The third museum is the private military weapons museum; it holds a group of monumental guns which were used in certain battles such as Abu Qir and Alexandria, in addition to some weapons that were used in the Western Desert battles during World War II. ${ }^{44}$

During the reign of King Fw' add and Farouq, the museums of the palace were open only to the royal family. ${ }^{45}$ In 1953 the haramlyk of the palace ${ }^{46}$ was turned into a museum and opened to visitors. ${ }^{47}$ The administration of the museum of 'Abdin was transferred to the museums administration in the Citadel. Then, it returned to the presidency under Sādāt, who ordered the renovation and restoration of the palace and the museum. ${ }^{48}$

Under the presidency of Mubārk, the palace was restored using the most up-to-date architectural methods. Part of the palace has been turned into a complex of museums for the exhibition of rare collections of weapons and artifacts. The Military Museum has been rearranged and the exhibition of the objects modernized. A hall displaying the various weapons presented to Mubārk has been added as well. Two additional specialized museums have been created. One of them displays the gifts received by Mubārk on various national occasions or during his worldwide tours. The other one is for Muhammad 'Alī's possessions of silver utensils and vessels, crystals, and colored glass, as well as other unique artifacts. ${ }^{49}$ The complex was given the new name of the Museums of 'Abdin Palace. Mubārk reopened it on October 17, 1998. Then on December 16, 2004, the Museum of Historical Documents was added to the museums of the palace. ${ }^{50}$ The palace now contains: the military museum of 'Abdin palace, the museum of silverware, the museum of historical documents and the museum of medals and decorations. ${ }^{51}$ This is in addition to the Royal Hunting Hall and the Presidency Gifts Museum.

Now two printed catalogues of the museum "Abdine Palace Museums" and "A Selection of the Displayed Collection at the Crystal, Chinaware and Gallé Museum" and one pamphlet "Selections of Abdeen Palace Museums" are available.

\section{- Farouq Rest House}

The rest house of King Farouq, known as Helwan Corner or Farouq Corner, lies on the road from Cairo to Helwan, some six kilometers from Helwan, overlooking the Nile. It was constructed on a piece of land belonging to the royal endowments (waqfs) and covers $11,600 \mathrm{~m}^{2} .^{52}$ The palace was erected on an area of $440 \mathrm{~m}^{2}$, while the garden, which was planted with rare plants and enclosed with a stone wall, occupied the rest of the area. ${ }^{53}$

The rest house of King Farouq in Helwan was bought with the money of the royal endowments (waqfs) in 1939 at the price of L.E. 2.000 and was furnished with antiques with an estimated value of L.E. 28.000. ${ }^{54}$ The house has a modern three-floor design. The ground floor contains servants' rooms, the kitchen, service sets, warehouses, lavatories and a terrace. It is directly

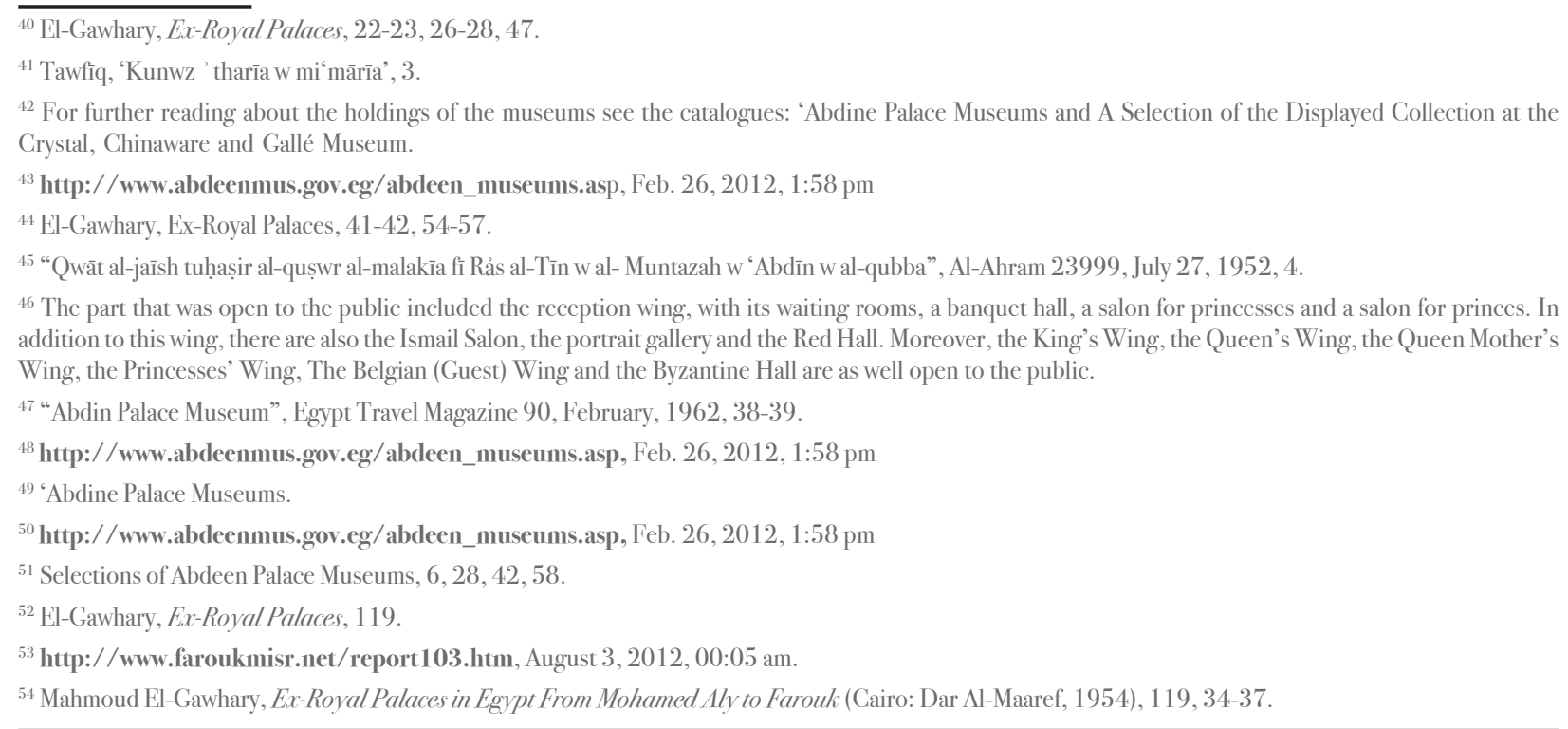


connected to the first floor. ${ }^{55}$

The first floor is the main one. A marble staircase leads to the outer lobby, which leads to the inner one, beyond which are two dining rooms and smoking areas overlooking the Nile. ${ }^{56}$ Also on this floor are the entrance hall, the grand saloon, bedrooms with annexes and a marble staircase leading to the roof. There is also a veranda with a pergola overlooking the Nile. In the dining room stands a pure crystal table, and glass cabinets containing a large collection of silver and Chinese vessels and vases. There are two bedrooms, each of which has a complete bathroom, a hall and a toilet and opens onto a marble-floored veranda. ${ }^{57}$ The second floor is the roof, reached by a marble staircase and used by the king for private evenings. ${ }^{58}$

The furniture is a selection taken from other palaces. It contains many antiques that were presented to the king on various occasions, with a value estimated at approximately L.E. 28,000. ${ }^{59}$ Although Farouq furnished it as befits kings and rulers, he visited it only twice during his reign. ${ }^{60}$

After the 1952 revolution, it continued to function as a rest house and was regarded as the property of the people. ${ }^{61}$ During the 1960 s, the rest house was open to the public for P.T. 4, and its garden was open free. ${ }^{62}$ In 1976 , it was placed under the supervision of the museums sector in the Supreme Council of Antiquities and designated as a monument. ${ }^{63}$

On July 13, 2009, the museum was open after restoration work which cost 1.5 million pounds and lasted for 6 months. All elements of the museum, including the main building, the garden, the stone corridors and the private laboratory, were renovated. This opening ceremony coincided with the Egyptian celebrations of International Museum Day. ${ }^{64}$

Like most Egyptian museums, the rest house has been closed for security reasons after the revolution of January $25,2011$. Thus, after being closed for 23 years for restoration, it was open for only a year, which was not enough to make people aware of the museum or to publish catalogues of its contents. ${ }^{65}$ Then on August 2, 2016 the museum was reopened by the Minister of Antiquities and Minister of Tourism. The Minister of Antiquities announced then that the rest house will be included in Hapi Nile cruise with the Egyptian Museum, Manyal Palace and Palace of Manasterly. ${ }^{66}$

\section{- Manyal Palace}

Manyal palace is unique among the princes' palaces of the dynasty of Muhammad 'Alī. Prince Muhammad 'Alī designed the plans and decorations of the palace and supervised the construction. It is located on the north of Ālrawḍa Island, facing the Cairo University Faculty of Medicine. It was built in 1901. The complex occupies an area of $61,711 \mathrm{~m}^{2}$, of which $5000 \mathrm{~m}^{2}$ is buildings, while the rest is the garden. ${ }^{67}$

The buildings manifest a unique style composed of Persian, Syrian, Moorish, Ottoman and rococo elements. Its fabulously eclectic architecture reflects its owner's taste. ${ }^{68}$ The complex consists of an enclosure wall ${ }^{69}$, entrance, reception $s a r \bar{a} y \bar{a}$

\footnotetext{
$\overline{55}$ El-Gawhary, Ex-Royal Palaces, 119-120.

${ }^{56}$ http://www.faroukmisr.net/report 103.htm, August 3, 2012, 00:05 am.

${ }^{57}$ El-Gawhary, Ex-Royal Palaces, 119-120.

${ }^{58}$ http://www.faroukmisr.net/report 103.htm, August 3, 2012, 00:05 am.

${ }^{59}$ El-Gawhary, Ex-Royal Palaces, 119.

${ }^{60}$ http://www.faroukmisr.net/report 103.htm, August 3, 2012, 00:05 am.

${ }^{61}$ http://www.faroukmisr.net/report 103.htm, August 3, 2012, 00:05 am.

${ }^{62}$ Egypt Travel Magazine 70, June 1960, 3.

${ }^{63}$ http://www.faroukmisr.net/report 103.htm, August 3, 2012, 00:05 am.

64 “Aiftitạ̣ rukn al-malik Farouq biḥilwān”, published in Ākhbar mișr July 13, 2009

http://www.masress.com/egynews/71987, December 3, 2012, 3:03 am.

${ }^{65}$ Phone call to the deputy of the museum of Farouq rest house, Azaa Muhammed Badawy, Dec. 4, 2012, 12:00 pm.

${ }^{66}$ Heba Adil, Bialșwar .. Iftitāḥ matḥaf rukn Farouq fi Ḥilwan ba 'd 5 'à 'wām min İ̉̆lāqih, Al Ahram Al Arabi, 2-8-2016, 13:11. http://arabi.ahram.org. eg/News/88708.aspx accessed on 24 March 2018, 2:53 pm.

67 ‘Ātịf Ghunaym, Qașr al-Amür Muhammad 'Al̄̄ (Cairo: Wizārat al-Thaqāfah, al-Majlis al-' a'la lil ’ athār), 9-10.

${ }^{68}$ Dan Richardson, Egypt. The Rough Guide (London: Cox \& Wyman, 1996), 155.

${ }^{69}$ The enclosure wall is in medieval style, built of limestone coated with rectangular sandstone pieces. The northern side of the enclosure is lined with guarding balconies. Parts of this enclosure are inscribed with Quranic verses in raised Kufic script.
} 
(salāmlyk) ${ }^{70}$, clock tower, Sabil, mosque, hunting museum ${ }^{71}$, residence sarāya $\bar{a}^{72}$, throne sarāyāa, private museum ${ }^{73}$, golden hall, mosque ${ }^{74}$ and a rare garden that surrounds the palace. The façade in general resembles the $4^{\text {th }}$ century Iranian mosques and schools. Many Islamic styles are incorporated in the design of the main entrance of the palace. ${ }^{75}$

The palace furnishings and prince's collections were given to the Egyptian Supreme Council of Antiquities in $1955,{ }^{76}$ after the death of the owner in $1954 .{ }^{77}$ During the 1960 s, the complex was open to the public. ${ }^{78}$

\section{A change of time}

Once opened, the palace museums attracted a lot of visitors and researchers. The visitors had different motivations to visit and study. Curiosity about the life of the royals, so recently fallen from power, was one reason. Admiration of the design, decorations, furniture, and antiques and the royal family's ambition of incorporating Egypt into European modernity and the globalized worldview that lay behind the bringing together of these items was another. The palaces were also monuments and symbols of the fall of the dictator. Another reason for many visitors to investigate the deserted homes was anger and resentment against the royal family's choice of how to spend the country's money.

This concerned the royal family's position and their expenditure of Egypt's money on the embellishment of their palaces and their own well-being, instead of using this money for projects in education or providing work opportunities that would have benefited the Egyptian population directly. ${ }^{79}$

The monthly Egyptian Travel Magazine from 1959 to 1963 added these three palaces to its list of museums to be visited in Egypt, with details about opening hours and ticket prices. In addition, photos from the interior of these palaces (especially Manyal Palace) were published in its first paper. ${ }^{80}$ In 1961 at Manyal Palace, Tourist administration officials welcomed tourists and distributed free pamphlets to them. Visitors greatly enjoyed the palace at that time. ${ }^{81}$ The Golden Hall of the Manyal Palace was also chosen for an international exhibition of tourist posters that was held on September 1960. ${ }^{82}$ The palaces are not now commonly on the tourist itinerary, but they are still part of the cultural program of Egyptian school classes.

During the end of the 1990s and the 2000s, great attention was paid in Egypt to monument conservation, and simultaneously there was a widespread growth in awareness among Egyptians of the importance of preserving their heritage for future generations. ${ }^{83}$ The Egyptian Culture Ministry paid great attention to the restoration of these former royal palaces. In 2008 , the ministry conducted a project to develop 45 museums, 10 of which were historical museums in different towns in Egypt. ${ }^{84}$ The Egyptian government renovated these museums because most visitors of museums are looking for positive, meaningful

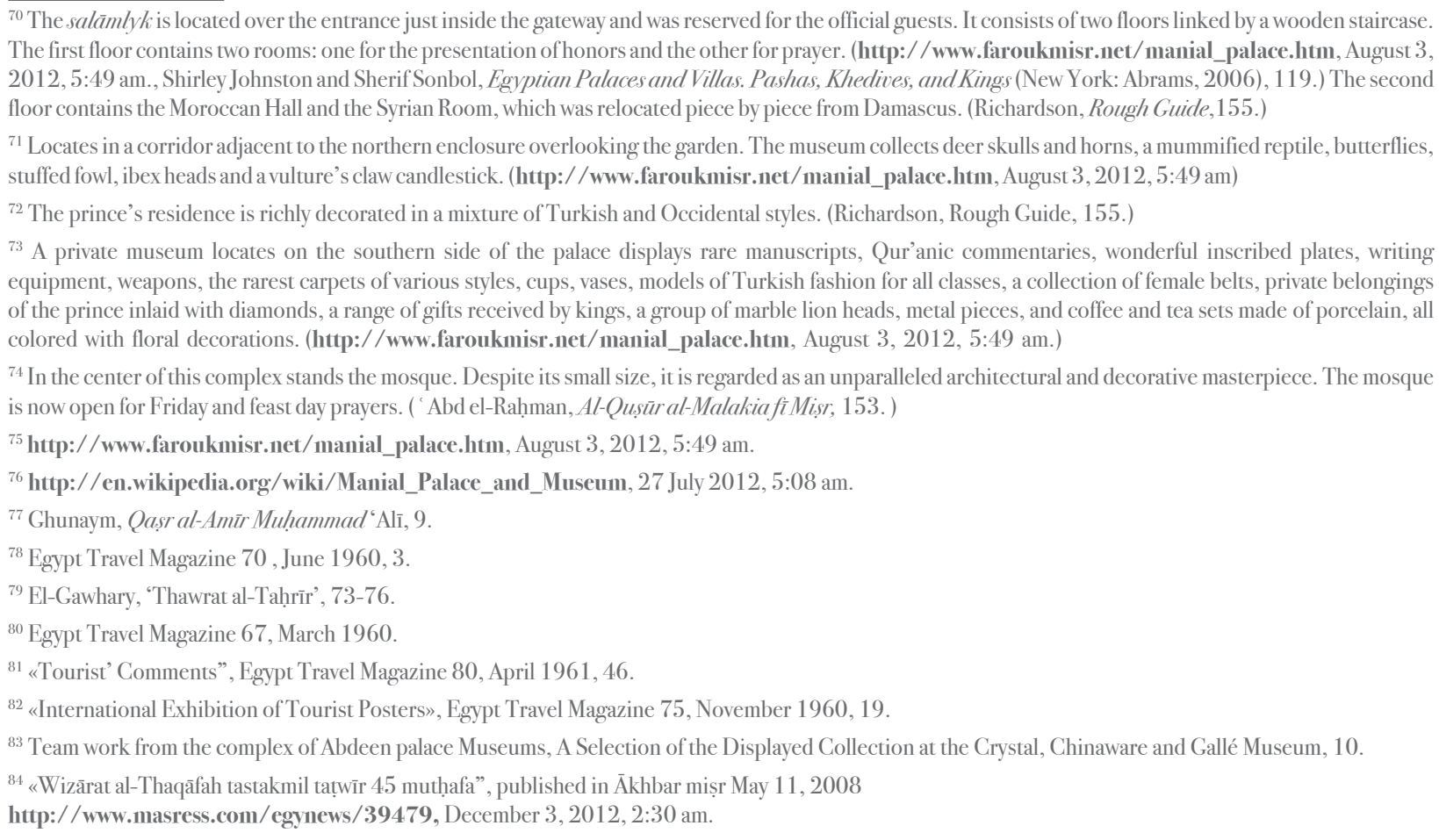


experience in museums. If they failed to find that sort of atmosphere, they may not be back. ${ }^{85}$ The former Egyptian King Ahmad $\mathrm{FW}_{\mathrm{W}}$ ād was pleased that the Egyptian government conducted such a project to restore the palaces of his dynasty and open them asmuseums. $^{86}$

Guide books for Egypt, such as the Blue Guide, Lonely Planet and the Rough Guide give careful attention to these palaces. The Lonely Planet guide for Egypt describes in detail how to reach 'Abdin Palace and Manyal Palace, which can be helpful to foreigners without tourist guides. In addition, it provides phone numbers and abstracts about the palaces. But the rest house of Farouq is not mentioned, as it was not open to the public in 2002. ${ }^{87}$ The Rough Guide also mentions 'Abdin palace and gives more detailed description of the Manyal Palace, its building, opening hours and the price of tickets. Again, Farouq rest house is not mentioned, as it was not open to the public in $1996 .{ }^{88}$ As for the Blue Guide, it gives abstracts about 'Abdin palace and Manyal Palace and the opening hours. As well as the two former guides, it does not mention Farouq rest house, as it was only opened to public in $2009 .^{89}$

Museums in the palaces under study can attract three groups of visitors. The first group are casual visitors, who move through a gallery quickly and display exit-oriented behaviour. Those can enjoy the gardens of the palaces much more than the interior and the displayed pieces. ${ }^{90}$ Those could be school students or people in vacation.

The second group are genuinely interested in the museum experience and the collections. However, they ordinarily do not spend much time reading, especially texts that appear difficult or require too much effort to understand. These visitors prefer a casual, headline approach to information display. ${ }^{91}$ This group could be university students specialized in art, tourism or architecture. Adults interested in art and architectures can fall also under this group.

The third group, who are the minority, will examine exhibitions with much more attention. These people spend a long time in the galleries, read the text and labels, and examine the objects closely. ${ }^{92}$ This one is more for researchers and scientific people who really care about information.

Palace museums under study can attract more visitors if they received more propaganda via different media and social media means. Organizing important events in those places can also help to promote visiting them. Communication and cooperation are also needed between those responsible in these museums and those responsible for the preparation of tourism programs to highlight the historical significance of these museums. Scientific materials suitable to their artistic and historical value should be provided to function as appropriate tourist propaganda.

\section{Conclusion}

After the 1952 revolution, the new regime made use of the royal palaces. The most magnificent ones were opened as historical museums representing the last phase of the Egyptian heritage before the outbreak of the revolution. The value of these palaces relates to its artistic and architectural value in addition to the political importance that they gained during the reign of the royal dynasty. Preserving these attractions is preserving an essential part of the Egyptian identity.

Immediately after opening, they attracted visitors for different reasons. Then they became a tourist attraction. With the passage of time they lost their position in tourist programs. This could be due to the focusing of the media on the Egyptian Pharaonic civilization and neglecting the modern attractions, which did not receive enough care and propaganda.

These palaces recently gained more attention from both the Ministry of Antiquities and Ministry of Tourism in addition to the efforts of the administration in these museums. They organize events in the halls of the museums commemorating the memory of the royal family and announce via social media to widely spread awareness of their activities.

\footnotetext{
${ }^{85}$ Dean, Museum Exhibition, 25.

${ }^{86}$ «Malik Miṣr al-sabiq Aḥmad Fouad sa 'īd bitarmī quṣwr āusratuh», published in Al-Shirwq Al-Jadīd April 27, 2010.

http://www.masress.com/shorouk/218788, December 3, 2012, 2:47am.

${ }^{87}$ Andrew Humphreys and Siona Jenkis, Egypt. Walk in the Shadows of the Pharaohs (Victoria: Lonely Planet, 2002), 170,176

${ }^{88}$ Richardson, Rough Guide, 98, 155.

${ }^{89}$ Veronica Seton-Williams and Peter Stocks, Blue Guide Egypt. Atlas, Street atlas of Cairo, maps, plans, and illustrations (London: A \& C Black, 1988), 210 ,

214

${ }^{90}$ Dean, Museum Exhibition, 25-26.

${ }^{91}$ Dean, Museum Exhibition, 25-26.

${ }^{92}$ Dean, Museum Exhibition, 25-26.
} 


\section{Bibliography}

- Dean, David. Museum Exhibition Theory and Practice, $3^{\text {rd }}$ ed.. London: Routledge, 1998.

- De Leon, Edwin. The Khedives's Egypt. London: Sampson Low,1877.

- El-Gawhary, Mahmoud. Ex-Royal Palaces in Egypt From Mohamed Aly to Farouk. Cairo: Dar Al-Maaref, 1954.

- 'abd al-Raḥman, Mạ̣mūd 'abās Āḥmmad. Al-Qușūr al-Malakia fì Miṣr Tārīkh w Ḥaḍara (1805-1952). Cairo: Al-Dār Al-`ālamīa lil Nashr w al-Tawzi ', 2005.

- Humphreys, Andrew and Siona Jenkis, Egypt. Walk in the Shadows of the Pharaohs, $6^{\text {th }}$ ed.. Victoria: Lonely Planet, 2002.

- Johnston, Shirley and Sherif Sonbol, Egyptian Palaces and Villas. Pashas, Khedives, and Kings. New York: Abrams, 2006.

- Mitchell, Timothy. Rule of Experts Egypt, Techno-Politics, Modernity. California: University of California, 2002.

- Mubārak, 'Alī Bāšā. al-Kittat al-Tawfíqiyya al-ǧadīda li-Miṣr al-Q̨āhira wa-mudunuhā wa-bilāduhā al-qadīma waalshahīra, vol. I. Tārīkh al-Q̄āhira wa Miṣr munzu al- 'asr al- Fāṭimị ḥata 'asr Tawfìq. $2^{\text {nd. }}$ ed. Cairo: al-Haî’a al-Maṣrīa al- 'āma lil Kitāb, 1994.

- Najm, ảbd al-Munsif Sālim. Qușūr al-umarā’ wa-al-bāshawāt fî madīnat al-Qāhirah fĩ al-qarn al-tāsi“ 'ashar, vol. II. Cairo: Maktabat Zahrā’ al-Sharq, 2002.

- Rāfíīi, 'Abd al-Raḥmān. 'Așrr Ismāêîl, vol. II. $4^{\text {th }}$ ed.. Cairo: Dār al-Ma ârif.

- Reid, Donald Malcolm. Whose Pharaohs? Archaeology, Museums, and Egyptian National Identity from Napoleon to World War I. London: University of California Press, 2002.

- Richardson, Dan. Egypt. The Rough Guide, $3^{\text {rd }}$ ed.. London : Cox \& Wyman, 1996.

- Rowlatt, Mary. Founders of Modern Egypt. London: Asia Publishing House, 1962.

- Seton-Williams, Veronica and Peter Stocks, Blue Guide Egypt. Atlas, Street atlas of Cairo, maps, plans, and illustrations, $2^{\text {nd }}$ ed.. London: A \& C Black, 1988.

- Tamarz, Nihal S.. Nineteenth-Century Cairene Houses and Palaces. Cairo: The American University in Cairo Press, 1998.

- Tugay, Emine Foat. Three Centuries Family Chronicles of Turke and Egypt. London: Oxford University Press, amen House, 1963.

\section{* Catalogues:}

- 'Abdine Palace Museums.

- Ghunaym, 'Āṭif. Qaașr al-Amīr Muḥammad 'Alī. Cairo: Wizārat al-Thaqāfah, al-Majlis al- ' a'la lil ' athār.

- Team work from the complex of Abdeen palace Museums. A Selection of the Displayed Collection at the Crystal, Chinaware and Gallé Museum. Cairo: Presidency Abdeen Palace Museums.

- Selections of Abdeen Palace Museums.

\section{* Conferences:}

- Konaré, Alpha Oumar. "Museums and Ethnological Heritage," Proceedings of the 12th General Conference and 13th General Assembly of the International Council of Museums (Mexico City: 25 October-4 November 1980): 65-67.

- Vázquez, Pedro Ramírez. "The Future of Heritage and the Heritage of the Future," Proceedings of the 12th General Conference and 13th General Assembly of the International Council of Museums (Mexico City: 25 October-4 November 1980), 48-54.

\section{* Periodicals:}

- El-Gawhary, Mahmoud, “Thawrat al-Tahrīi fĩ al-Qușwr al-Malakīa”, Al-Hilal 61 part 7 (July 1953), 73-76.

- Pretes, Michael. “Tourism and Nationalism”, Annals of Tourism Research vol. 30, no. 1 (2003), 125-126. 


\section{* Magazines:}

- Egypt Travel Magazine 70 (June 196o): 3.

- “Abdin Palace Museum”, Egypt Travel Magazine 90 (February 1962): 38-41.

- Egypt Travel Magazine 67 (Mars 1960).

- “Tourist' Comments”, Egypt Travel Magazine 80 (April 1961), 46.

- "International Exhibition of Tourist Posters", Egypt Travel Magazine 75 (November 1960), 19.

\section{* News Papers:}

- "Qwāt al-jaīsh tuḥașir al-qușwr al-malakīa fì Ra's al-Tīn w al- Muntazah w 'Abdīn w al-qubba”, Al-Ahram 23999, 27 July 1952.

- "Qaṣr “Abdīn lil rīāsa w qașr al-qubba lil ḍiāfa”, Al-Ahram 31085, 19 Jan. 1972.

- Tawfíq, Ryāḍ. «Kunwz 'tharīa w mi'mārīa 'abda tha 'usrat Muḥammad 'Aly Bāsha .. al-Baḥth 'n Qaậr lil Ri' asa», Al-Ahram 45742, 2 March 2012.

\section{* Websites:}

- http://modernegypt.bibalex.org/TxtViewer/TextViewer. aspx?ID=299\&type=Article, $16 \quad$ July $2012, \quad 2: 38 \quad$ am.

- http://www.abdeenmus.gov.eg/abdeen_museums.asp, 26 Feb. 2012, 1:58 pm

- http://www.faroukmisr.net/report103.htm, 3 August 2012, 00:05 am.

- http://www.faroukmisr.net/manial_palace.htm, 3 August 2012, 5:49 am.

- http://en.wikipedia.org/wiki/Manial_Palace_and_Museum, 27 July 2012, 5:08 am.

- “Aiftitaḥ rukn al-malik Farouq bihiilwān”, published in Ākhbar miṣr 13 July 2009. http://www. masress.com/egynews/71987, 3 December 2012, 3:03 am.

- "M' al-ra' ̄̄s Muḥammad Nagib fî Qașr Ra's al-Tīn”, Al-Mușwir, 26 Sep. 1952. http://modernegypt.bibalex.org/DocumentViewer/TextViewer. aspx ${ }^{w}=1258 \& \mathrm{~h}=598 \&$ type $=$ press\&id $=3248 \& \mathrm{~s}=1, \quad 3 \quad$ December $\quad 2012, \quad 1: 40 \quad \mathrm{am}$.

- "Wizārat al-Thaqāfah tastakmil tațwīr 45 mutḥafa", published in Ākhbar miṣr 11 May 2008. http://www.masress.com/egynews/39479, 3 December 2012, 2:30 am.

- "Malik Miṣr al-sabiq Aḥmad Fouad sa 'īd bitarmī quṣwr āusratuh», published in Al-Shirwq AlJadīd 27 April 2010. http://www.masress.com/shorouk/218788, 3 December 2012, 2:47am.

- Heba Adil, Bialșwar .. Iftitāḥ matḥaf rukn Farouq fi Hilwan ba ' d 5 ' ā 'wām min Iğlāqih, Al Ahram Al Arabi, 2-8-2016, 13:11. http://arabi.ahram.org.eg/News/88708.aspx accessed on 24 March 2018, 2:53 pm. 